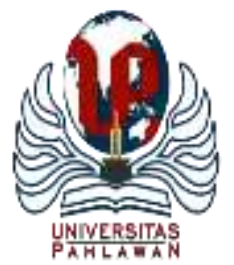

Edukatif : Jurnal Ilmu Pendidikan Volume 4 Nomor 1 Tahun 2022 Halm 1193 - 1203

EDUKATIF: JURNAL ILMU PENDIDIKAN

Research \& Learning in Education

https://edukatif.org/index.php/edukatif/index

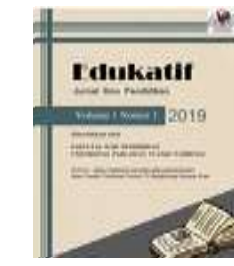

\title{
Pengaruh Self-Efficacy, Minat Menjadi Guru, dan Teman Sebaya Terhadap Pengambilan Keputusan Memilih Program Studi Pendidikan Akuntansi
}

\author{
Ade Nur Indah Yuliawan ${ }^{1 凶}$, Han Tantri Hardini \\ Universitas Negeri Surabaya, Indonesia ${ }^{1,2}$ \\ E-mail : ade.18032@mhs.unesa.ac.id ${ }^{1}, \underline{\text { hanhardini@unesa.ac.id }}^{2}$
}

\begin{abstract}
Abstrak
Tujuan dari penelitian ini untuk mengetahui ada tidaknya pengaruh antara variabel self-efficacy, minat menjadi guru, dan teman sebaya terhada pengambilan keputusan memilih program studi pendidikan akuntansi. Populasi dan sampel ini adalah mahasiswa pendidikan akuntansi angkatan 2021 menggunakan metode probability ssampling. Metode pengumpulan data terdiri dari penyebaran kuesioner menggunakan google form, yang dibagikan kepada sampel peneliti. Metode analisis data menggunakan analisis regresi linier berganda menggunakan aplikasi SPSS 25 Windows. Hasil penelitian ini menunjukkan bahwa variabel-variabel seperti self-efficacy, minat menjadi guru dan teman sebaya secara simultan mempengaruhi variabel pengambilan keputusan dalam memilih program studi pendidikan akuntansi dibuktikan dengan besarnya $\mathrm{F}_{\text {tabel }}$ sebesar 2,736. Karena nilai $F_{h i t u n g} 22,834>F_{\text {tabel }}$ 2,736. Secara parsial self-efficacy mempengaruhi pengambilan keputusan dibuktikan dari uji t sebesar $0,000<0,05$, minat menjadi guru tidak mempengaruhi pengambilan keputusan dibuktikan dari uji t sebesar 0,611>0,05 dan teman sebaya mempengaruhi pengambilan keputusan memilih program studidibuktikan dari uji t sebesar 0,050>0,05.
\end{abstract}

Kata Kunci: Self-Efficacy, Minat Menjadi Guru, Teman Sebaya dan Pengambilan Keputusan

\section{Abstract}

The purpose of this study was to determine whether there was an influence between the variables of selfefficacy, interest in being a teacher, and peers on the decision to choose an accounting education study program. This population and sample are accounting education students batch 2021 using the probability sampling method. The data collection method consisted of distributing questionnaires using a google form, which was distributed to a sample of researchers. The data analysis method used multiple linear regression analysis using the SPSS 25 Windows application. The results of this study indicate that variables such as selfefficacy, interest in being a teacher, and peers simultaneously affect the decision-making variables in choosing an accounting education study program as evidenced by the magnitude of the $F_{\text {table }}$ of 2.736 . Because the value of $F_{\text {count }} 22.834>F_{\text {table }} 2.736$. Partially self-efficacy affects decision-making as evidenced by the t-test of $0.000<0.05$, interest in being a teacher does not affect decision-making as evidenced by the $t$ test of $0.611>0.05$, and peers influence decision-making to choose a study program as evidenced by the t-test of $0.050>0.05$.

Keywords: Self-Efficacy, Interest in Becoming a Teacher, Peers and Decision Making

Copyright (c) 2022 Ade Nur Indah Yuliawan, Han Tantri Hardini

$\triangle$ Corresponding author:

Email : ade.18032@mhs.unesa.ac.id

DOI : https://doi.org/10.31004/edukatif.v4i1.2076

ISSN 2656-8063 (Media Cetak)

ISSN 2656-8071 (Media Online)

Edukatif : Jurnal Ilmu Pendidikan Vol 4 No 1 Tahun 2022 p-ISSN 2656-8063 e-ISSN 2656-8071 
1194 Pengaruh Self-Efficacy, Minat Menjadi Guru, dan Teman Sebaya Terhadap Pengambilan Keputusan Memilih Program Studi Pendidikan Akuntansi - Ade Nur Indah Yuliawan, Han Tantri Hardini

DOI: https://doi.org/10.31004/edukatif.v4i1.2076

\section{PENDAHULUAN}

Pendidikan merupakan proses pengembangan yang sangat penting guna mencerdaskan bangsa dan negara sebagai upaya meningkatkan kualitas SDM di masa depan. Menurut Peraturan Pemerintah RI No. 57, (2021) bahwa individu yang memiliki pemikiran positif tentang pendidikan dapat tunjukkan dari perilakunya yaitu adanya ketertarikan dengan dunia pendidikan sehingga dapat menumbuhkan dan mengembangkan potensi diri dengan cara menuntut ilmu ke tingkat pendidikan yang lebih tinggi. Sebab, pendidikan merupakan peranan penting untuk mengembangkan potensi lewat pengajaran. Jenjang pendidikan di lembaga pendidikan Indonesia, mulai tingkat pendidikan dasar sampai perguruan tinggi (Firdaus, 2021). Perguruan tinggi merupakan sebuah lembaga yang memiliki tugas untuk menyelenggarakan pendidikan dan pengajaran yang didasarkan pada kebangsaan Indonesia menggunakan cara ilmiah. Perguruan tinggi negeri di Jawa Timur adalah salah satu nya Universitas Negeri Surabaya (Unesa). Program studi pendidikan akuntansi mengajarkan keilmuan bidang akuntansi dan bidang pendidikan yang mana untuk karir nya bisa berprofesi menjadi guru ataupun akuntan. Program studi pendidikan akuntansi Unesa per tahun menerima mahasiswa baru yang tentunya memiliki kualitas yang baik. Maka calon mahasiswa yang memiliki keinginan untuk dapat diterima di program studi pendidikan akuntansi tentunya akan berusaha untuk mencapai hal tersebut. Proses pengambilan keputusan menurut Kolter \& Keller (2019) adalah memilih keputusan untuk mendaftar agar dapat melaksanakan kegiatan yang telah dipilih. Jadi dengan mengambil keputusan untuk mendaftar di program studi pendidikan akuntansi dan mengikuti serangkaian tes adalah salah satu proses agar dapat diterimanya pada perguruan tinggi yang diinginkan. Berikut adalah data pendaftar di program studi pendidikan akuntansi Universitas Negeri Surabaya.

\section{Tabel 1}

Data Pendaftaran Prodi Pendidikan Akuntansi 2017-2021

\begin{tabular}{|c|c|c|c|c|}
\hline \multirow{2}{*}{ Tahun } & \multicolumn{3}{|c|}{ Jalur pendaftaran } & \multirow{2}{*}{ Jumlah } \\
\hline & SBMPTN & SBMPTN & Mandiri & \\
\hline 2017 & 414 & 483 & 60 & 957 \\
\hline 2018 & 378 & 432 & 60 & 870 \\
\hline 2019 & 191 & 304 & 245 & 740 \\
\hline 2020 & 197 & 276 & 64 & 537 \\
\hline 2021 & 174 & 202 & 0 & 376 \\
\hline
\end{tabular}

Sumber: Sipenmaru Unesa tahun 2017-2021

Berdasarkan data pada tabel 1. diatas disimpulkan bahwa terjadi penurunan pendaftar pada program studi pendidikan akuntansi. Hal ini dapat dijelaskan bahwa calon mahasiswa memiliki keputusan sendiri dalam menentukan program studi sesuai dengan keinginannya. Berdasarkan data penurunan calon mahasiswa yang mendaftar di program studi pendidikan akuntansi tersebut, peneliti ingin mengetahui keterkaitan variabel yang mempengaruhi pengambilan keputusan tersebut.

Pengambilan keputusan merupakan keputusan seseorang dalam memilih beberapa pilihan yang sebelumnya sudah dipertimbangkan dan disesuaikan dengan kemampuan yang dimiliki guna untuk tercapainya harapan yang diinginkannya. Hal ini sesuai menurut Supranto (2020) bahwa Pengambilan keputusan merupakan memilih satu alternative yang terbaik dari sekian banyak pilihan alternative yang sebelumnya sudah dipertimbangkan dan diambil yang paling menguntungkan dalam pengambilan keputusan tersebut. Selain itu menurut Simon (2016) pengambilan keputusan yaitu memilih tindakan untuk mencapai tujuan. Apabila seseorang yang merasa memiliki tujuan dan kemampuan di dunia pendidikan akuntansi hanya dengan belajar di dunia pendidikan akuntansi maka, seseorang tersebut dapat berkembang dan berguna. Sebelum mahasiswa memutuskan untuk memilih alternative yaitu memilih program studi pendidikan akuntansi juga dapat dipengaruhi oleh kekuatan eksternal dan internal. Maka, peneliti melakukan observasi awal dengan melakukan wawancara pada 15 responden dengan hasil bahwa mahasiswa mengambil keputusan 
1195 Pengaruh Self-Efficacy, Minat Menjadi Guru, dan Teman Sebaya Terhadap Pengambilan Keputusan Memilih Program Studi Pendidikan Akuntansi - Ade Nur Indah Yuliawan, Han Tantri Hardini

DOI: https://doi.org/10.31004/edukatif.v4i1.2076

untuk memilih program studi pendidikan akuntansi Unesa karena adanya pengaruh dari keyakinan diri (selfefficacy), motivasi karir, teman sebaya, keluarga, dan minat menjadi guru. Dari hasil variabel tersebut peneliti ingin memperkuat variabel yang ingin diteliti dengan memberikan pertanyaan lewat penyebaran kuesioner menggunakan google form. Berikut adalah hasil observasi awal menggunakan kuesioner google form sebagai berikut:

Tabel 2

Hasil Observasi Kuesioner

\begin{tabular}{cc}
\hline Faktor pengambilan keputusan & Persentase \\
\hline Keyakinan Diri (Self-Efficacy) & $26.6 \%$ \\
\hline Minat Menjadi Guru & $20 \%$ \\
\hline Motivasi Karir & $13.3 \%$ \\
\hline Teman Sebaya & $26.6 \%$ \\
\hline Keluarga, & $13.3 \%$ \\
\hline
\end{tabular}

Sumber: Google form yang disebar peneliti

Berdasarkan hasil observasi awal diatas bahwa ada 3 variabel yang persentase terbanyak yang digunakan peneliti untuk diteliti. Maka dari hasil observasi awal diperoleh hasil bahwa mengambil keputusan untuk memilih program studi pendidikan akuntansi di Unesa karena adanya pengaruh dari variabel selfefficacy, teman sebaya dan minat menjadi guru.

Selain itu Menurut Reed dkk (2020) bahwa ada faktor yang mempertimbangkan self-efficacy dalam pengambilan keputusan. Kemudian menurut Tarigan (2019) Self-efficacy sangat dibutuhkan karena memiliki sifat kepercayaan dalam diri dan pantang menyerah menghadapi masalah timbul setelah mengambil keputusan. Self-efficacy ini menggambarkan bagaimana seseorang melihat kemampuannya ketika dihadapkan dengan masalah (Galyon, 2019). Berdasarkan pernyataan diatas semakin tinggi self-efficacy maka kemampuan beradaptasi dan percaya diri besar dalam pengambilan keputusan untuk menyelesaikan masalah. Begitu juga sebaliknya jika self-efficacy rendah maka kemampuan kepercayaan dalam diri dan adaptasi sekitar yang rendah dapat mengorbankan peluang atau tidak menerapkan tindakan yang diterapkan dalam pengambilan keputusan (Bandura \& Wood, 2010). Oleh karena itu kepercayaan terhadap pilihan yang diambil sangat penting. Hal ini membuat penelitian ini penting sehingga dalam memilih program studi pendidikan akuntansi diperlukan self efficacy. Hal ini juga didukung dalam penelitian Winanti (2016) pada 183 mahasiswa. Hasilnya bahwa ada hubungan yang signifikan antara self-efficacy terhadap pengambilan keputusan.

Faktor internal lainnya yang diduga berpengaruh terhadap pengambilan keputusan adalah minat. Minat merupakan salah satu faktor internal untuk mempertimbangkan pengambilan keputusan memilih program studi (Bawantara, 2019; Risnawati \& Irwandi, 2018). Selain itu, menurut Slameto (2019) minat adalah perasaan lebih suka dan rasa tertarik pada suatu hal atau tindakan, tanpa ada yang menyuruh. Minat pada dasarnya adalah pengakuan hubungan antara diri sendiri dan sesuatu di luar diri sendiri. Sebagaimana ditunjukkan oleh Usman, (2018) guru adalah instruktur yang tugasnya mengajar siswa dalam perspektif yang berbeda. Artinya, seseorang yang memiliki keyakinan untuk mencapai hal yang ideal tergantung pada kegembiraan dan minat pada sesuatu. Seperti ketika seseorang menjadi seorang pendidik yang akan menghasilkan pendapatan sendiri, misalnya pada mahasiswa program studi pendidikan akuntansi. Ini cenderung mencari data tentang menjadi seorang pendidik. Hampir bisa dipastikan, hal itu akan berdampak padanya untuk lebih tertarik dan menyiratkan apakah mahasiswa yang memilih program studi pendidikan akuntansi ini benar-benar dimulai dari minat untuk menjadi seorang pendidik kompetitor. Minat menjadi seorang pendidik merupakan salah satu faktor pendorong dalam pilihan untuk memilih program studi pendidikan akuntansi. Didukung dari penelitian Sulistyawati, dkk (2017) minat berpengaruh positif terhadap pengambilan keputusan. Tinjauan ini juga sesuai penelitian Siswanto dkk.,( 2017) bahwa ada pengaruh positif antara minat terhadap memilih keputusan. Mengingat penjelasan di atas bahwa semakin tinggi minat untuk menjadi guru semakin tinggi pula arah dalam memilih program studi begitu juga sebaliknya. 
Berdasarkan penelitian Suriyani (2016) Faktor eksternal pengambilan keputusan diantaranya adalah teman sebaya. Singh \& Saini (2019) mengatakan bahwa teman sebaya adalah seseorang yang berasal dari masyarakat yang sama asosiasi berdasarkan usia, kelas. Sedangkan teman adalah orang yang berhubungan dengannya berdasarkan kasih sayang dan kekaguman. Rata-rata teman seseorang paling banyak menghabiskan waktu bersama dengan teman sebaya akibatnya seseorang selalu berusaha untuk cocok satu dengan yang lain. Maka teman sebaya dapat berpengaruh positif dan dapat juga berpengaruh negative. Oleh sebab itu, ketika melakukan pengambilan keputusan seseorang harus pintar dalam mempertimbangkan pengaruh tersebut. Berdasarkan pernyataan diatas dapat disimpulkan bahwa. Teman sebaya dapat berpengaruh positif dan dapat juga berpengaruh negative terhadap pengambilan keputusan mahasiswa. Mempertimbangkan terlebih dahulu pengaruh teman sebaya sebelum menentukan pengambilan keputusan adalah hal yang harus dilakukan. Sebab teman merupakan pengaruh dari luar individu yang dapat berdampak baik dan buruk tentunya juga memerlukan pertimbangan untuk mengatasi pengaruh tersebut. Hal ini juga didukung dari Hasil penelitian Hernita (2019) pada 87 Mahasiswa dan penelitian Istiqomah (2018) pada 665 mahasiswa bahwa terdapat pengaruh yang signifikan dari variabel teman sebaya terhadap pengambilan keputusan, dibuktikan dengan responden memiliki kekompakan yang tinggi, mudah menerima, dan mudah bersosialisasi dengan teman baru.

Mahasiswa pendidikan akuntansi di Universitas Negeri Surabaya tentunya menginginkan masa depan yang cerah dan tentunya harus didasarkan dengan usaha untuk tercapainya hal yang diinginkan. Apabila tidak memiliki keyakinan diri, minat, dan dukungan teman dekat. Mahasiswa akan kesulitan dalam menentukan keputusannya dalam memilih program studi. Ketika seseorang dengan tegas mengambil keputusan yang didasari oleh komitmen dan informasi yang memadai Maka, dapat per potensi pengambilan keputusan dapat menyelesaikan masalah yang dihadapi atau dapat tercapainya harapan yang diinginkannya. Maka peneliti menduga pengambilan keputusan dapat dipengaruhi oleh banyak faktor pendukung diantaranya pengaruh selfefficacy, minat menjadi guru, dan teman sebaya. Kepercayaan diri dimiliki oleh Setiap manusia begitu juga dengan minat seseorang menjadi pendidik karena dengan kepercayaan diri dan minat yang ada dalam diri seseorang yang kuat mampu membangkitkan semangat terhadap pendidikan. Begitu pula dengan seseorang yang memiliki lingkungan teman pergaulan yang dapat berperan untuk meningkatkan motivasi terhadap pendidikan. Tetapi kenyataannya sering dijumpai permasalahan seseorang yang memiliki kepercayaan diri rendah, belum optimal nya minat seseorang menjadi guru, dan lingkungan teman sebaya yang dapat berpengaruh negatif.

Berdasarkan pemaparan fenomena diatas, peneliti ingin mengkaji lebih dalam terkait dengan bagaimana "pengaruh self-efficacy, minat menjadi guru dan teman sebaya terhadap pengambilan keputusan memilih program studi pendidikan akuntansi" dengan tujuan peneliti yaitu untuk melihat apakah self-efficacy, minat menjadi guru dan teman sebaya memiliki pengaruh signifikan baik secara simultan ataupun parsial terhadap pengambilan keputusan memilih program studi pendidikan akuntansi.

\section{METODE PENELITIAN}

Jenis pemeriksaan ini menggunakan kuantitatif. Faktor-faktor dalam tinjauan ini menggunakan variabel terikat dan variabel bebas. Pada self-efficacy (X1), Minat menjadi guru (X2) dan Teman sebaya (X3) sebagai variabel bebas, sedangkan variabel terikat yang digunakan adalah pengambilan keputusan (Y) dalam penelitian ini: 
1197 Pengaruh Self-Efficacy, Minat Menjadi Guru, dan Teman Sebaya Terhadap Pengambilan Keputusan Memilih Program Studi Pendidikan Akuntansi - Ade Nur Indah Yuliawan, Han Tantri Hardini

DOI: https://doi.org/10.31004/edukatif.v4i1.2076

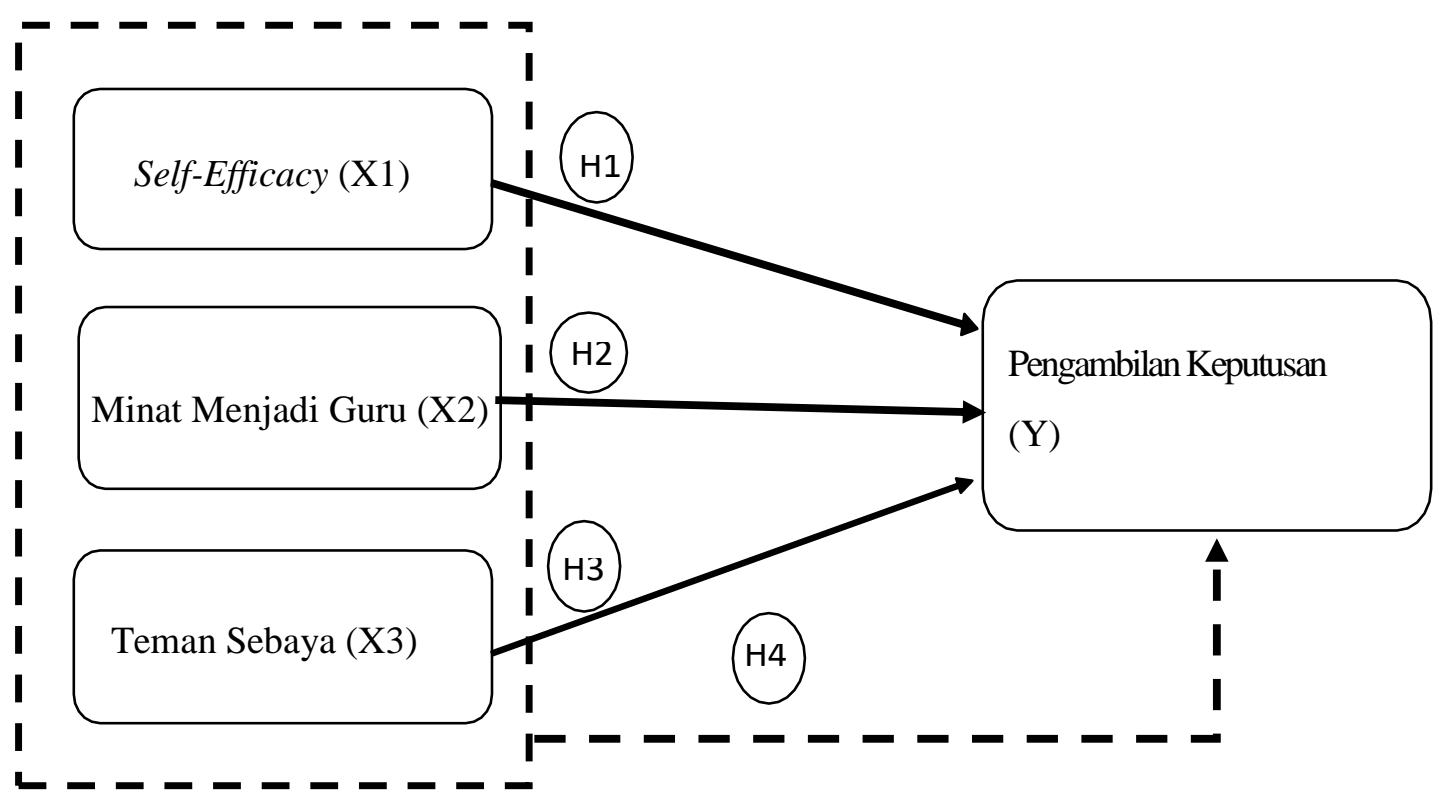

Gambar 1. Desain Penelitian

Sumber: Data diolah peneliti (2021)

Populasi ini adalah mahasiswa pendidikan akuntansi angkatan 2021 Unesa dengan 74 mahasiswa. Tinjauan ini menggunakan metodologi pengujian pendahuluan dengan kemungkinan di mana seluruh daerah memiliki peluang yang sama untuk menjadi contoh. Alasan untuk survei ini adalah untuk memilih apakah pengaruh self-efficacy, minat menjadi guru, dan teman sebaya dalam pengambilan keputusan untuk memilih program studi pendidikan akuntansi. Prosedur pengumpulan data untuk pemilihan informasi dalam tinjauan ini menggunakan sumber data primer dan data sekunder. Diperoleh data primer dengan penyebaran kuesioner atau angket kepada sampel melalui google form pada 74 mahasiswa dan wawancara terhadap 10 mahasiswa sedangkan data sekunder diperoleh melalui berbagai sumber seperti jurnal dan buku. Survei berupa responden diberikan yang diberikan secara langsung atau dikirim melalui pos atau web (Sugiyono, 2018). Kuisioner ini menggunakan skala likert. Skala likert berguna mengukur persepsi, pendapat seseorang mengenai sesuatu peristiwa pengukuran persepsi, pendapat, dan sikap individu terhadap hal yang terjadi (Pranatawijaya 2019). Skala yang digunakan dalam instrument ini menggunakan skala likert dengan alternatif jawaban diantaranya Sangat Tidak Setuju (STS), Tidak Setuju (TS), Ragu-Ragi (RR), Setuju (S), dan Sangat Setuju (SS).

Pada penelitian ini ada dua skala pengukuran nya yaitu positif dan negatif kemudian untuk tingkat bobot skor dalam penelitian ini yang disesuaikan dengan tipe kesukaan adalah sebagai berikut:

Tabel 3

Tingkat skor

\begin{tabular}{ccc}
\hline \multirow{2}{*}{ Keterangan } & \multicolumn{2}{c}{ Skor } \\
& Pertanyaan Positif & Pertanyaan Negatif \\
\hline SS & 5 & 1 \\
\hline S & 4 & 2 \\
\hline RR & 3 & 3 \\
\hline TS & 2 & 4 \\
\hline STS & 1 & 5 \\
\hline
\end{tabular}

Nilai/skor pada jawaban tersebut yang bernilai positif diberi skor dengan urutan tabel pertanyaan positif. Sedangkan pada pernyataan negative diberikan nilai dengan urutan tabel pertanyaan negative. Instrumen penelitian ini pada variable self-efficacy disusun berdasarkan aspek-aspek seperti ungkapan menurut Bandura, (2017) yaitu, magnitude (tingkat kesulitan melakukan usaha), strength (kekuatan keyakinan), dan generality (penyederhanaan berlebihan). Kemudian, variabel minat menjadi seorang pendidik 
1198 Pengaruh Self-Efficacy, Minat Menjadi Guru, dan Teman Sebaya Terhadap Pengambilan Keputusan Memilih Program Studi Pendidikan Akuntansi - Ade Nur Indah Yuliawan, Han Tantri Hardini

DOI: https://doi.org/10.31004/edukatif.v4i1.2076

diperkirakan melalui informasi tentang profesi guru, kecintaan, perhatian, keinginan, dan keyakinan menjadi pendidik. Sedangkan variabel pendamping dinilai dari tanda kerjasama, mudah mengenal teman baru, mudah menyesuaikan diri, dan senang menghabiskan waktu dengan siapa saja.

Analisis data menggunakan analis regresi linier berganda dengan bantuan aplikasi SPSS 25 for Windows untuk menguji hipotesis yang ada. Data ini dari kuesioner yang kemudian dikumpulkan dan diolah menggunakan beberapa uji statistik yaitu: uji Asumsi Klasik (uji normalitas, uji muItikolinearitas, uji heteroskedasitas), uji t uji $\mathrm{F}$ dan uji koefisien determinan.

\section{HASIL DAN PEMBAHASAN PENELITIAN}

Penelitian ini menggunakan uji asumsi klasik sebagai pra syarat untuk melanjutkan analisis uji statistik parametric yang digunakan untuk menjawab hipotesis penelitian ini. Berikut adalah hasil uji asumsi klasik (uji normalitas, uji muItikoIinearitas dan uji heteroskedastisitas.)

\section{Uji Normalitas}

Berdasarkan uji normalitas dengan grafik normal P.P PIot of regression standardized residuaI bahwa nilai residual ber distribusi normal dengan nilai signifikansi kolmogrov smirnov 0,200 atau >0,05. Maka hasil menunjukkan bahwa residual ber distribusi secara normal.

\section{Uji Multikolinearitas}

Hasil uji multikolinearitas menunjukkan bahwa nilai standart error yaitu variabel self-efficacy sebesar $0,102<1$, variabeI minat menjadi guru sebesar $0,082<1$ dan variabel teman sebaya sebesar $0,115<1$. Serta nilai koefisien beta variabel self-efficacy sebanyak $0,591<1$, variabel minat menjadi guru $0,042<1$, dan teman sebaya sebesar 0,229 < 1 . Maka dapat dikatakan bahwa nilai standart eror rendah dan multikoliniearitas tidak terdeteksi. Selanjutnya pada variabel self-efficacy memiliki nilai VIF sebesar 1,315 < 10 dapat diartikan bahwa variabeI self-efficacy tidak berkorelasi sempurna, variabel minat menjadi guru memiliki nilai VIF sebesar 1,399 < 10 artinya bahwa variabel minat menjadi guru tidak berkorelasi sempurna, dan variabel teman sebaya memiliki nilai VIF sejumlah $1,442<10$ diartikan bahwa variabel teman sebaya tidak berkorelasi sempurna. Sehingga diperoleh kesimpulan bahwa hasil uji multikolinearitas dari ketiga variabel menunjukkan daIam modeI regresi tidak terdapat gejaIa muItikoIinearitas.

\section{Uji hesterokedasitas}

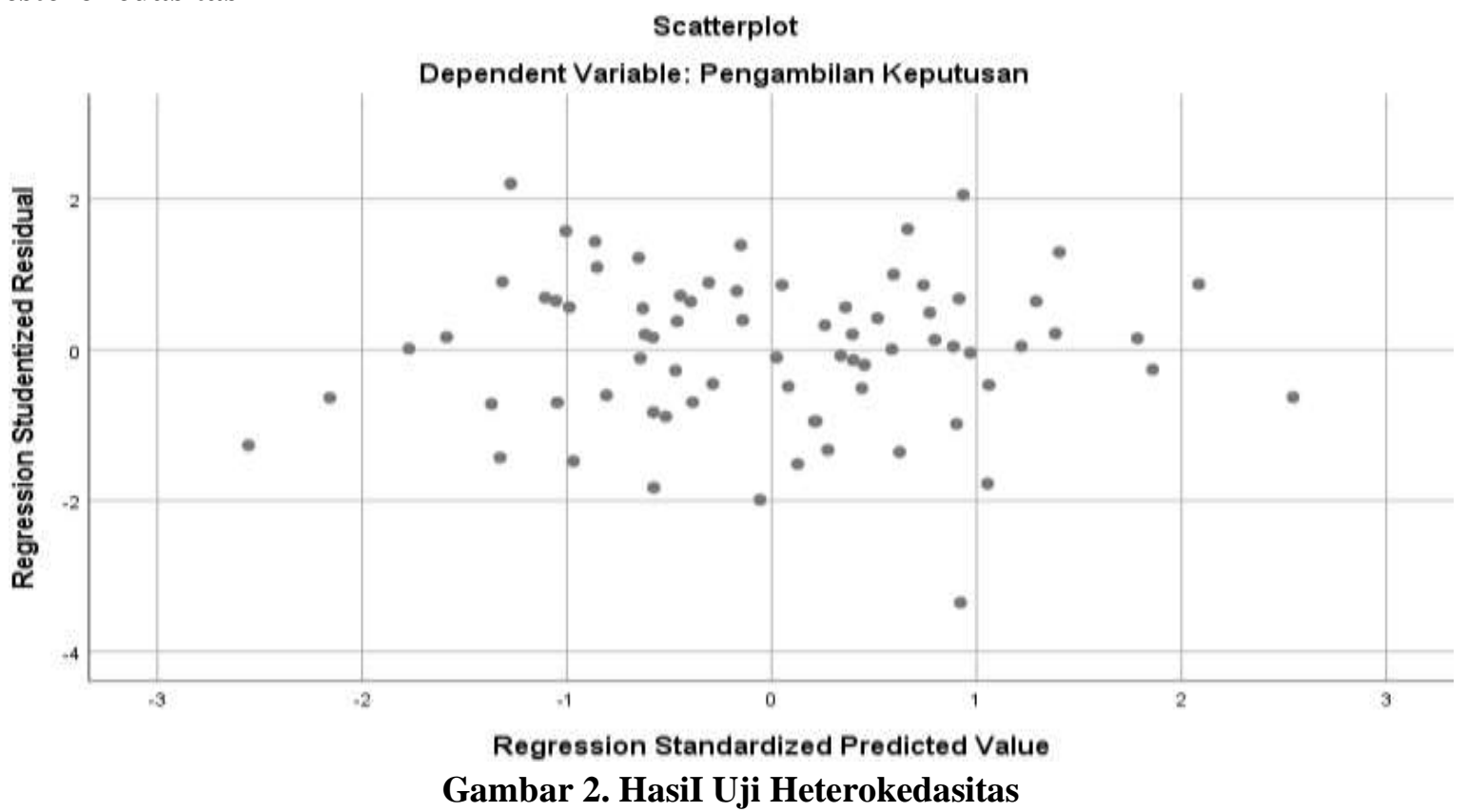

Edukatif : Jurnal Ilmu Pendidikan Vol 4 No 1 Tahun 2022 p-ISSN 2656-8063 e-ISSN 2656-8071 
1199 Pengaruh Self-Efficacy, Minat Menjadi Guru, dan Teman Sebaya Terhadap Pengambilan Keputusan Memilih Program Studi Pendidikan Akuntansi - Ade Nur Indah Yuliawan, Han Tantri Hardini

DOI: https://doi.org/10.31004/edukatif.v4i1.2076

Hasil dari uji hesteroskedasitas pada tabel dengan nilai signifikan $>0,05$ dan pada grafik scatterplot diperoleh hasil bahwa data menyebar secara luas atau acak atau bisa dikatakan tidak berbentuk seperti pola tertentu, maka tidak terdapat gejala adanya heteroskedasitas dalam penelitian modellregresi. Setelah dilakukan uji asumsi kIasik yaitu uji normalitas, uji muItikolinearitas dan uji heteroskedasitas kemudian dilakukan analisis linier berganda dengan hasil sebagai berikut:

\section{Analisis Regresi Linier Berganda}

Dilihat dari coefficients diperoleh hasil:

$$
\mathrm{Y}=2,149+0,591 \mathrm{X}_{1}+0,042 \mathrm{X}_{2}+0,229 \mathrm{X}_{3}
$$

Keterangan;

$\mathrm{X}_{1}=$ Self - Efficacy

$\mathrm{X}_{2}=$ Minat Menjadi Guru

$\mathrm{X}_{3}=$ Teman Sebaya

$\mathrm{Y}=$ Pengambilan Keputusan

Berdasarkan hasil dari analisis regresi linier berganda menyiratkan bahwa: (1) konsistennya adalah 2,149 yang berarti bahwa jika variabel self-efficacy (X1), minat menjadi guru (X2), dan teman sebaya (X3) bernilai 0, maka pengambilan keputusan (Y) senilai 2,149 . (2) Koefisien regresi Iinier berganda pada variabel self-efficacy (X1) adalah 0,591; Artinya jika self-efficacy bertambah 1 satuan, sedangkan variabel minat menjadi guru (X2) dan teman sebaya (X3) memiliki nilai yang tetap, maka pengambilan keputusan (Y) akan mengalami pertambahan senilai 0,591. (3) Koefisien regresi linier berganda variabel minat menjadi guru(X2) adalah 0,042; Artinya jika minat menjadi guru meningkat 1 satuan, sedangkan variabel variabel self-efficacy (X1) dan teman sebaya (X3) bernilai tetap, maka pada saat itu variabel pengambilan keputusan (Y) akan mengalami penurunan senilai 0,042. (4) Koefisien regresi linier berganda pada variabel teman sebaya (X3) adalah 0,229; Artinya dengan asumsi teman sebaya mengalami kenaikan 1 satuan, sedangkan variabel selfefficacy (X1) dan minat menjadi guru (X2) nilainya tetap, maka pada saat itu variabel pengambilan keputusan (Y) akan bertambah sebesar 0,229.

\section{HasiI Uji F (Pegujian Secara SimuItan)}

\section{Tabel 4}

HasiI Uji F (Pegujian Secara SimuItan)

\begin{tabular}{ccccc|c|c}
\hline & & \multicolumn{2}{c}{ ANOVA $^{\mathbf{a}}$} & F & Sig. \\
\hline Model & Sum of Squares & Df & Mean Square &, $000^{\mathrm{b}}$ \\
\hline Regression & 647,468 & 3 & 215,823 & 22,834 & \\
\cline { 2 - 7 } & Residual & 661,627 & 70 & 9,452 & & \\
\hline Total & 1309,095 & 73 & & & \\
\hline
\end{tabular}

a. Dependent VariabIe: Pengambilan Keputusan

b. Predictors: (Constant), Teman Sebaya, SeIf-Efficacy, Minat Menjad Guru

$$
\begin{aligned}
& \mathrm{F}_{\text {tabeI }} \text { diperoleh dengan perhitungan sebagai berikut: } \\
& \begin{aligned}
\mathrm{F}_{\text {tabeI }} & =\mathrm{F}(\mathrm{k}: \mathrm{n}-\mathrm{k}) \\
& =\mathrm{F}(3: 74-3) \\
& =\mathrm{F}(3: 71) \\
& =2,736
\end{aligned}
\end{aligned}
$$

Berdasarkan hasil tersebut menunjukkan bahwa besarnya $F_{\text {tabel }}$ sebesar 2,736. Kaena nilai $F_{\text {hitung }} 22,834$ $>\mathrm{F}_{\text {tabel }} 2,736$, maka dapat disimpulkan bahwa hipotesis diterima dan sig. adalah $0,000<0,05$ jadi, dinyatakan variabeI seIf-efficacy, minat menjadi guru, dan teman sebaya bersama sama atau simultan memberikan pengaruh signifikan terhadap variabel pengambilan keputusan memilih program studi pendidikan akuntansi. 
1200 Pengaruh Self-Efficacy, Minat Menjadi Guru, dan Teman Sebaya Terhadap Pengambilan Keputusan Memilih Program Studi Pendidikan Akuntansi - Ade Nur Indah Yuliawan, Han Tantri Hardini

DOI: https://doi.org/10.31004/edukatif.v4i1.2076

\section{Hasil Uji t}

Tabel 5

Hasil Uji T (Pengujian Secara Parsial)

Coefficients $^{\mathbf{a}}$

\begin{tabular}{|c|c|c|c|c|c|c|}
\hline & \multirow[b]{2}{*}{ Model } & \multicolumn{2}{|c|}{ Unstandardized Coefficients } & \multirow{2}{*}{$\begin{array}{c}\text { Standardized } \\
\text { Coefficients } \\
\text { Beta }\end{array}$} & \multirow[b]{2}{*}{$\mathrm{t}$} & \multirow[b]{2}{*}{ Sig. } \\
\hline & & B & Std. Error & & & \\
\hline \multirow[t]{4}{*}{1} & (Constant) & 2,149 & 4,092 & & ,525 & ,601 \\
\hline & Self-Efficacy &, 591 & ,102 & 564 & 5,789 &, 000 \\
\hline & Minat Menjadi Guru & ,042 & ,082 & 051 &, 511 & 611 \\
\hline & Teman Sebaya & ,229 & ,115 & ,202 & 1,982 &, 050 \\
\hline
\end{tabular}

a. Dependent VariabIe: Pengambilan Keputusan

Dilihat dari tabeI koefisien di atas, bahwa hasil uji t atau uji parsial variabel self-efficacy, minat menjadi guru dan teman sebaya adalah sebagai berikut: (1) variabeI seIf-efficacy (X1) dinyatakan berpengaruh positif dan sig. terhadap pengambilan keputusan $(\mathrm{Y})$. Ditunjukkan dengan besarnya $\mathrm{T}^{\text {hitung }}$ sebesar 5,789 $>\mathrm{T}^{\text {tabel }}$ sebesar 1,666 dimana nilai signifikan sejumlah $0,000<0,05$. (2) Variabel minat menjadi guru (X2) menyatakan bahwa tidak ada pengaruh yang pasti dan kritis terhadap pengambilan keputusan. Dibuktikan dengan besarnya $\mathrm{T}^{\text {hitung }}$ sebesar 0,511 $<\mathrm{T}^{\text {taber }}$ sebesar 1,666 dimana nilai signifikan sejumlah 0,611 >0,05. (3) Variabel teman sebaya (X3) dinyatakan mempengaruhi pengambiIan keputusan (Y). Hal ini ditunjukkan dengan besarnya $T^{\text {hitung }}$ sebesar 1,982 $>T^{\text {tabel }}$ sebesar 1,666 dimana nilai signifikan sejumlah 0,050 $>0,05$. Begitu juga dengan koefisien beta dinormalisasi bahwa besar kecilnya variabel bebas mempengaruhi variabel terikat. Adapun faktor yang mempengaruhi antara lain variabel self-efficacy sebesar 0,564, variabel minat menjadi guru sebesar 0,051, dan variabel teman sebaya sebesar 0,202 .

\section{HasiI Pengujian R2 (Koefisien Determinasi)}

\section{Tabel 6}

HasiI Pengujian R2 (Koefisien Determinasi)

\begin{tabular}{cc|cccc}
\hline \multicolumn{5}{c}{ Model Summary } \\
Model & R & R Square & Adjusted R Square & Std. Error of the Estimate \\
\hline 1 &, $703^{\mathrm{a}}$ &, 495 &, 473 & 3,074 \\
\hline
\end{tabular}

a. Predictors: (Constant), Teman Sebaya, Self-Efficacy, Minat Menjad Guru

Bedasarkan tabel model summary didapatkan nilai $\mathrm{R}$ square senilai 0,473 yang memiliki arti variabel self-efficacy, minat menjadi guru dan teman sebaya berpengaruh pada variabeI pengambiIan keputusan 49,5\%.Ssedangkan kelebihan dari nilai 51,5\% adalah faktor yang tidak diperiksa oleh peneliti.

\section{Ada Pengaruh Self-Efficacy, Minat Menjadi Guru Dan Teman Sebaya Terhadap Pengambilan Keputusan}

Uji F yang didapatkan hasil $F^{\text {hitung }}$ sebesar 22,834 > $F^{\text {tabel }}$ sebesar 2,736 dimana nilai signifikan $0,000<$ 0,05 sehingga dikatakan bahwa pengaruh bersamaan antara variabel self-efficacy, minat menjadi guru dan teman sebaya untuk menentukan pilihan memilih program studi akuntansi. Dengan koefisien assurance (R2) yang terletak di Changed $\mathrm{R}$ Square diperoleh nilai sebesar 0,473, berarti bahwa self-efficacy, minat menjadi guru dan teman sebaya memiliki komitmen sebesar $47,3 \%$ dalam menentukan pilihan untuk memilih keputusan. Demikian pula nilai sisa yaitu $52,7 \%$, dipengaruhi oleh faktor-faktor yang tidak dimanfaatkan oleh peneliti, misalnya inspirasi profesi, landasan keluarga, konsentrasi pada ketenaran program, aspek sosialkeuangan, dan lain-lain.

Koefisien determinan (R2) memiliki arti penting dari tiga variabel bebas, yaitu self-efficacy, menjadi menjadi guru dan teman sebaya menambah kontribusi kepada mahasiswa dalam menentukan pilihan untuk memilih program studi pendidikan akuntansi. Hal tersebut dikarenakan tingginya keyakinan self-efficacy 
1201 Pengaruh Self-Efficacy, Minat Menjadi Guru, dan Teman Sebaya Terhadap Pengambilan Keputusan Memilih Program Studi Pendidikan Akuntansi - Ade Nur Indah Yuliawan, Han Tantri Hardini

DOI: https://doi.org/10.31004/edukatif.v4i1.2076

yang baik dalam diri mahasiswa berpengaruh terhadap pengambilan keputusan, minat untuk menjadi guru berpengaruh pada pengambilan keputusan dimasa depan, dan teman sebaya yang berpengaruh positif terhadap pengambilan keputusan. Oleh sebab itu, kepercayaan diri mahasiswa yang berkompeten dihasilkan dari self-efficacy mahasiswa terhadap keputusan mengambil program studi pendidikan akuntansi. Ketertarikan dan keinginan mahasiswa pada profesi guru akuntansi dihasilkan dari minat mahasiswa menjadi guru terhadap keputusan mengambil prodi pendidikan akuntansi. Persepsi positif teman sebaya terhadap pengambilan keputusan mahasiswa dalam memilih keputusan memilih prodi pendidikan akuntansi.

\section{Ada Pengaruh Self-Efficacy Terhadap Pengambilan Keputusan}

SeIf-efficacy adalah keyakinan atau kepercayaan individu terhadap sesuatu yang akan diselesaikan. Adanya kemampuan keyakinan diri yang tinggi menunjukkan bahwa individu dapat menghadapi kesulitan dengan baik dan maksimal. Jadi, keyakinan diri seseorang menyiratkan kepercayaan seseorang dalam mencapai sesuatu dan sebaliknya. Hal ini sejalan dengan pengujian hipotesis oleh Winanti, (2016)bahwa semakin tinggi self-eficacy individu, semakin mudah untuk menghadapi kesulitan. Dalam perspektif ini, "orang adalah kontributor untuk keadaan hidupnya, bukan hanya produknya" (Bandura, 2020) karena ada kecenderungan untuk mengutamakan kinerja tugas yang diyakini memiliki tingkat efikasi diri tinggi. Keyakinan efikasi diri juga terkait dengan usaha dan ketekunan serta waktu yang dihabiskan untuk mengerjakan suatu tugas, serta cara penyelesaian rintangan yang dihadapi oleh seseorang (Myburgh, 2020). Dalam hal ini tinggi rendahnya self-efficacy mempengaruhi kepercayaan diri mahasiswa dalam menentukan pilihannya. Tergantung pada keyakinan dalam diri mahasiswa dalam menganalisis untuk melakukan hal yang diinginkannya.

Hasil berdasarkan uji-t diperoleh nilai $\mathrm{T}^{\text {hitung }}$ sebesar 5,789 > $\mathrm{T}^{\text {tabel }}$ sebesar 1,666 dimana nilai sig. sebesar $0,000<0,05$. Maka, dikatakan $\mathrm{H}_{0}$ diterima. Jadi bisa dikatakan bahwa ada dampak positif dan sig. antara self-efficacy terhadap pengambilan keputusan memilih program studi. Sejalan dari tinjauan ini sesuai dengan penelitian Al-Faraqi, (2020) bahwa ada pengaruh yang sig. antara kelompok referensi dan self efficacy terhadap pengambilan keputusan, selain itu sejalan dengan Prabowo, (2010) bahwa ada hubungan variabel self efficacy terhadap Pengambilan keputusan menentukan jurusan kuliah.

\section{Tidak Ada Pengaruh Minat Menjadi Guru Terhadap Pengambilan Keputusan}

Minat menjadi guru adalah suatu sensasi cinta dan ketertarikan pada panggilan yang menunjukkan dan kebutuhan untuk menemukan dan melihat lebih dalam lagi tentang menjadi pendidik Minat muncul dari diri sendiri tanpa intimidasi dari orang lain. Ketika seseorang memiliki minat pada profesi pendidik, orang tersebut memiliki motivasi untuk menyelesaikan sesuatu sesuai keinginannya dan juga sebaliknya. Hal ini sesuai dengan penilaian Hurlock (2015)bahwa minat merupakan sumber motivasi bagi individu untuk mendorongnya melakukan apa yang ingin dilakukannya.

Dari hasil uji t diperoleh $\mathrm{T}^{\text {hitung }} 0,511<\mathrm{T}^{\text {tabel }} 1,666$ dimana nilai sig. sebesar 0,611 >0,05. Jadi orang mungkin mengatakan bahwa tidak ada efek yang pasti dan besar pada minat untuk menjadi guru terhadap pengambilan keputusan. Hal ini terlihat dari hasil pertemuan dengan responden bahwa alasan tidak berpengaruh nya minat menjadi pendidik dalam memilih program studi pendidikan akuntansi adalah karena mahasiswa kurang tertarik terhadap program studi, mahasiswa tertarik untuk menjadi guru tetapi tidak pada program studinya, mahasiswa asal memilih program studi dan diterima. Selain itu, dilihat dari hasil perhitungan dari sudut penunjuk menunjukkan bahwa masih rendahnya pengetahuan dan kecintaan dan pekerjaan untuk menjadi seorang pendidik.

\section{Ada Pengaruh Teman Sebaya Terhadap PengambiIan Keputusan}

Teman sebaya yang diidentifikasi satu sama lain dan berasal dari masyarakat yang sama. Seperti yang diungkapkan oleh Albert dkk, (2019) bahwa banyak orang menghabiskan energi paling ekstrem nya dengan teman-temannya dari pada dengan keluarganya. Selanjutnya muncul asosiasi dan koneksi yang nyaman antara 
1202 Pengaruh Self-Efficacy, Minat Menjadi Guru, dan Teman Sebaya Terhadap Pengambilan Keputusan Memilih Program Studi Pendidikan Akuntansi - Ade Nur Indah Yuliawan, Han Tantri Hardini

DOI: https://doi.org/10.31004/edukatif.v4i1.2076

sahabat. Pada situasi ini, apakah teman mempengaruhi hubungan dalam memutuskan keputusan bergantung pada kemampuan seseorang untuk mempertimbangkan dari sudut pandang untuk mengukur asumsi.

Dilihat dari uji t, hasil menunjukkan bahwa $\mathrm{T}^{\text {hitung }}$ adalah 1,982 $>\mathrm{T}^{\text {tabel }}$ adalah 1,666 dimana nilai sig. sebesar adalah $0,050<0,05$, sehingga dapat dikatakan bahwa $\mathrm{H} 0$ ditolak dan Ha diakui. Ini menyiratkan bahwa ada dampak positif dan signifikan antara teman sebaya terhadap pengambilan keputusan. Hal ini sesuai penelitian Yuniawati, (2015)bahwa ada pengaruh serentak guru dan teman sebaya terhadap pilihan mahasiswa dalam memilih LBB. Sejalan juga dengan penelitian Hernita, (2019) bahwa teman sebaya, lingkungan keluarga berpengaruh positif dan signifikan terhadap pengambilan keputusan dalam memilih jurusan, sesuai juga dengan penelitian Istiqomah, dkk, (2018) bahwa ada pengaruh umum dari kesamaan teman, inspirasi, dan minat pada program di perguruan tinggi, baik sampai batas tertentu atau pada waktu yang sama.

\section{KESIMPULAN}

Berdasarkan tinjauan ini, hasil penelitian menunjukkan bahwa: ada pengaruh antara variabel selfefficacy, minat menjadi guru, dan teman sebaya secara simuItan terhadap pengambilan keputusan, ada pengaruh yang positif dan signifikan antara Self-efficacy terhadap pengambilan keputusan, tidak ada pengaruh yang positif dan signifikan antara variabel minat menjadi guru terhadap pengambilan keputusan, ada pengaruh yang positif dan signifikan pada variabel teman sebaya terhadap pengambilan keputusan memilih program studi pendidikan akuntansi.

\section{DAFTAR PUSTAKA}

Al-Faraqi, F. (2020). Pengaruh Kelompo Referensi Dan Efikasi Diri Terhadap Pengambilan Keputusan Dalam Memilih Jurusan Kedokteran Siswa Kelas XII IPA SMA N 1 Samarida. PSIKOBORNEO: Jurnal Ilmiah Psikologi, 3(2), 112-121.

Amini, F. (2018). pengaruh pemilihan program studi pendidikan ekonomi terhadap minat menjadi guru bagi mahasiswa pendidikan ekonomi 2014. Jurnal Pendidikan Ekonomi (JUPE), 6(2).

Ana, T.\& Sudarno. (2016). Analisis Faktor-Faktor Yang Mempengaruhi Keputusan Mahasiswa Memilih Program Studi Pendidikan Ekonomi FKIP UNS (Studi Pada Angkatan 2014 dan 2015). Jurnal Pendidikan Ekonomi Dan Bisnis. UNS - Fak. KIP Jur. Pend. Ekonomi - K7412172 - 2016, 1-15.

Firdaus, A. A. (2021). Dampak Covid-19Terhadap Kebiajakan Pendidikan di Indonesia: antara Idealisme dan Realitas. In F. Setiawan \& U. H. Salsabila (Eds.), UAD PRESS. UAD PRESS.

https://www.google.co.id/books/edition/Dampak_Covid_19_Terhadap_Kebijakan_Pendi/lo4mEAAAQ $\mathrm{BAJ} ? \mathrm{hl}=\mathrm{en} \& \mathrm{gbpv}=1 \& \mathrm{dq}=$ pembelajaran+online+berhasil+ditinjau+dari\&pg=PA104\&printsec=frontcov er

Hayurika, T \& Sandy. (2015). Analisis Faktor-Faktor Yang Mempengaruhi Minat Siswa Dalam Pengambilan Keputusan Memilih Jurusan Akuntansi Kelas X Di Smk N 1 Demak. Jurnal Pendidikan Ekonomi Dinamika Pendidikan, 10(1), 88-103. https://doi.org/10.15294/dp.v10i1.5097

Hernita, N. (2019). Pengaruh Teman Sebaya Dan Lingkungan Keluarga Terhadap Pengambilan Keputusan Dalam Memilih Jurusan. Jurnal Ilmiah Ekonomi Dan Keuangan Syariah, I, 35-44.

Indonesia, P. R. (2021). Peraturan Pemerintah Republik Indonesia Nomor 57.

Irnawati, D. (2019). Pengaruh Minat Menjadi Guru Terhadap Keputusan Mahasiswa Memilih Program Studi Pendidikan Ekonomi Fakultas Ekonomi Universitas Negeri Makassar. Diploma Thesis, Universitas Negeri Makassar., 1-24.

Istiqomah, D. (2018). Pengaruh Konformitas Teman Sebaya, Motivasi Dan Minat Karir Terhadap Pemilihan Program Studi Akuntansi Di Perguruan Tinggi. Jurnal Riset Pendidikan Ekonomi, 3(2), 1-8. https://doi.org/10.21067/jrpe.v3i2.3801

Karpinski, D. (2020). Relationship Between The Self-efficacy And The Stages Of The Decision-Making 
1203 Pengaruh Self-Efficacy, Minat Menjadi Guru, dan Teman Sebaya Terhadap Pengambilan Keputusan Memilih Program Studi Pendidikan Akuntansi - Ade Nur Indah Yuliawan, Han Tantri Hardini

DOI: https://doi.org/10.31004/edukatif.v4i1.2076

Process : Analysis Of The Future Managers' Perception Relação entre a Autoeficácia e os Estágios do Processo Decisório: Análise da Percepção dos Futuros Administradores. The Redalyc Project Is a Bibliographic Database and a Digital Library of Open Access Journals, Supported by the Universidad Autónoma Del Estado de México, 792-807. https://doi.org/10.5902/1983465934132

Leslie, B. \& Moilanne, J. (2010). Advancing Self-Efficacy and Intuitive Decision-Making Calls to Action. Adualt Education Research Conferremce, New Prairie Press, Kansas State University Libraries, 576 577.

Prabowo, dkk. (2010). Hubungan Antara Student Self-Efficacy Dan Persepsi Terhadap Harapan Orang Tua Dengan Pengambilan Keputusan Menenrukan Jurusan Kuliah Pada Siswa SMA N 3 Magelang. Jirnal Pendidikan Psikologi dan Pendidikan, 1-8.

Pranatawijaya, dkk. (2019). Penerapan Skala Likert dan Skala Dikotomi Pada Kuesioner Online. Jurnal Sains Dan Informatika, 5(2), 128-137. https://doi.org/10.34128/jsi.v5i2.185

Siswanto, dkk. (2017). Pengaruh Minat, Konsep Diri, Dan Persepsi Tentang Profesi Guru Terhadap Keputusan Memilih Program Studi Pendidikan Akuntansi Universitas PGRI Madiun. THE 13th FIPA, 193-201.

Sulistyawati. (2017). Pengaruh Minat, Potensi Diri, Dukungan Orang Tua, Dan Kesempatan Kerja Terhadap Keputusan Mahasiswa Memilih Jurusan Akuntansi Program S1 Universitas Pendidikan Ganesha. EJournal S1 Ak Universitas Pendidikan Ganesha, 8(2), 1-12.

Sunaryo. (2017). Pengukuran Self-Efficacy Siswa dalam Pembelajaran Matematika di MTsN 2 Ciamis. TEOREMA : Teori Dan Riset Matematika, 1(2), 39. https://doi.org/10.25157/teorema.v1i2.548

Suriyani. (2016). Faktor-Faktor yang Mempengaruhi Keputusan Mahasiswa dalam Memilih Jurusan Akuntansi Program S1 di Universitas Pendidikan Ganesha. Ekuitas: Jurnal Pendidikan Ekonomi, 4(2). https://doi.org/10.23887/ekuitas.v4i2.12792

Tarigan, E. (2019). Effect Of Self-Efficiency On Decision Making In Solving Problems Of Math. Jurnal Pionir LPPM Universitas Asahan, 18-24.

UNESA. (2021). Sistem Informasi Penerimaan Mahasiswa Baru 2020/2021. Sipenmaru.Unesa. https://sipenmaru.unesa.ac.id/data_pendaftar

Verma, \& Bansal. (2019). Decision Making among Adolescents in relation to Peer Pressure. The International Journal of Indian Psychology, 7(4). https://doi.org/10.25215/0704.020

Winanti. (2016). Korelasi Self-Efficacy Dengan Pengambilan Keputusan Melanjutkan Studi Pada Mahasiswa Fakultas Tarbiyah Dan Keguruan UIN Raden Intan Lampung Angkatan 2016. Undergraduate Thesis, UIN Raden Intan Lampung.

Yuniawati. (2015). Pengaruh Guru dan Teman Sebaya Terhadap Keputusan Peserta Didik Dalam Memilih Lembaga Bimbingan Belajar ( Studi Pada Lembaga Bimbingan Belajar Primagama Driyorejo - Gresik). Jurnal Pendidikan Akuntansi, Universitas Negeri Surabaya, 1-9. 